\title{
PENGARUH METODE BERCERITA TERHADAP KETERAMPILAN BERBICARA PADA PEMBELAJARAN BAHASA INDONESIA KELAS IV SD NEGERI MANGKURA IV MAKASSAR
}

\author{
Tamara Wigita, Hambali, Andi Adam. \\ Pendidikan Guru Sekolah Dasar, Fakultas Keguruan dan Ilmu Pendidikan, \\ Universitas Muhammadiyah Makassar \\ Iqramsyar34@gmail.com
}

\begin{abstract}
ABSTRAK
Masalah yang melatarbelakangi penelitian ini adalah rendahnya aktifitas murid, kebanyakkan murid yang takut dan malu untuk berbicara di depan umum. Adapun rumusan masalahnya adalah apakah ada pengaruh metode bercerita terhadap keterampilan berbicara pada pembelajaran Bahasa Indonesia kelas IV Sekolah Dasar Negeri Mangkura 4 Makassar. Penelitian ini bertujuan Untuk mengetahui pengaruh metode bercerita terhadap keterampilan berbicara pada pembelajaran Bahasa Indonesia kelas IV Sekolah Dasar Negeri Mangkura 4 Makassar. Penelitian ini adalah Penelitian ini merupakan penelitian korelatif (hubungan) dengan pendekatan kuantitatif. Penelitian hubungan bertujuan untuk mengetahui hubungan antara dua variabel atau lebih serta mengetahui pengaruhnya. Pada pelaksanakannya dilaksanakan sebanyak tiga kali pertemuan. Prosedur penelitian meliputi perencanaan, pelaksanaan tindakan, dan Evaluasi. Subjek penelitian adalah muris kelas IV SD Negeri Mnagkura 4 Makassar. Teknik pengumpulan data yang digunakan adalah observasi, tes dan dokumentasi sedangkan teknik analisis data yang digunakan adalah teknik analisis kuantitatif Hasil perhitungan analisis hipotesis yang dilaksanakan kelas IV SD Negeri Mangkura 4 Makassar Kecamatan Ujung Pandang, Kelurahan Sawerigading, Kota Makassar, Sulawesi Selatan sebesar adalah 0.558. Selain uji hipotesis diuji juga dengan nilai koefisien determinasi sebesar $31.13 \%$. Uji terakhir yang dilakukan adalah uji signifikansi untuk mengetahui apakah hipotesis yang dibuat dari awal diterima atau ditolak dari. Hasil uji signifikansi adalah sebesar 3.560. Nila rata-rata sebesar $72,82 \%$ dengan kategori baik maka dari hasil penelitian menunjukan jika metode bercerita dan keterampilan berbicara saling berpengaruh dalam hasil belajar dan aktivitas belajar murid. Berdasarkan hasil penelitian menunjukan jika metode bercerita dan keterampilan berbicara saling berpengaruh dalam hasil belajar dan aktivitas belajar murid.
\end{abstract}

Kata Kunci: Metode Bercerita; Keterampila Berbicara. 


\section{PENDAHULUAN}

Keterampilan berbicara merupakan salah satu aspek keterampilan dasar dalam berbahasa. Menurut Djiwandono, M. Soenardi (1996: 68), berbicara merupakan kegiatan berbahasa yang aktif dari seorang penggunaan bahasa, yang menuntut prakarsa nyata dalam penggunaan bahasa untuk mengungkapkan diri secara lisan. Tarigan, Henry Guntur (2008: 16) yang mengemukakan berbicara adalah kemampuan mengucapkan bunyi-bunyi artikulasi atau kata-kata untuk mengekspresikan, menyatakan serta menyampaikan pikiran, gagasan, dan perasaan. Senada dengan pendapat tersebut. berbicara adalah peristiwa proses penyampaian pesan secara lisan oleh pembicara kepada penerima pesan. Dengan kata lain, berbicara adalah menyampaikan pesan melalui bahasa lisan.

Salah satu upaya untuk meningkatkan keterampilan berbicara yaitu menggunakan metode yang tepat. Metode yang dirasa tepat adalah metode bercerita. Metode bercerita dapat memacu kecerdasan linguistik. Metode ini akan mendorong murid memiliki kemampuan verbal yang sangat esensial dalam kehidupan manusia. Tidak hanya itu, dari bercerita murid akan belajar tata cara berdialog dan bernarasi. Metode ini mendorong murid untuk senang bercerita atau berbicara. Setelah memperoleh pengalaman bercerita, murid akan berpikir untuk menunjukkan eksistensi diri. Hal ini memacu murid untuk belajar berbicara lebih baik lagi.

Guru perlu memilih metode yang tepat dalam pembelajaran Bahasa Indonesia. Pemilihan metode yang tepat akan mampu mengembangkan keterampilan berbicara melalui penggunaan metode yang tepat. Salah satu upaya untuk mengembangkan keterampilan berbicara murid yaitu menggunakan metode yang tepat dan yang dirasa tepat adalah metode bercerita.

Metode bercerita mendorong murid untuk senang bercerita. Setelah memperoleh pengalaman bercerita, murid akan berpikir untuk menunjukkan eksistensi diri. Hal ini memacu murid untuk belajar berbicara lebih baik lagi. Memacu keterampilan berbicara merupakan sesuatu yang penting, karena keterampilan berbicara mempengaruhi penyesuian sosial dan pribadi seseorang.

Berdasarkan uraian yang dipaparkan di atas, maka dirasa perlu untuk mengadakan penelitian tentang pengaruh metode bercerita terhadap keterampilan berbicara. 
Berdasarkan uraian di atas rumusan masalah dalam penelitian ini adalah: "Apakah ada pengaruh metode bercerita terhadap keterampilan berbicara pada pembelajaran Bahasa Indonesia kelas IV Sekolah Dasar Negeri Mangkura 4 Makassar?". Tujuan penelitian ini adalah mengetahui: Untuk mengetahui pengaruh metode bercerita terhadap keterampilan berbicara pada pembelajaran Bahasa Indonesia kelas IV Sekolah Dasar Negeri Mangkura 4 Makassar.

\section{Konsep Bahasa Indonesia}

Menurut Sibarani (2004: 37) bahasa sebagai sistem tanda atau sistem lambang, sebagai alat komunikasi dan digunakan oleh kelompok manusia atau masyarakat. Bahasa Indonesia merupakan mata pelajaran yang membelajarkan murid untuk berkomunikasi dengan baik dan benar. Komunikasi ini dilakukan baik secara lisan maupn tertulis. Dengan kesimpulan tersebut, maka standar kompetensi mata pelajaran Bahasa Indonesia merupakan kualifikasi kemampuan minimal murid yang menggambarkan penugasan, pengetahuan, keterampilan berbahasa, sikap positif terhadap bahasa.

Pembelajaran Bahasa Indonesia saat ini telah mencakup seluruh aspek kebahasaan, maka murid dituntut mampu berkomunikasi secara efektif, selalu menggunakan Bahasa Indonesia sebagai alat komunikasi formal, memahami Bahasa Indonesia dan menggunakannya dengan tepat, serta mampu membanggakan Bahasa Indonesia sebagai budaya Indonesia disertai rasa bangga terhadap budayanya sendiri.

\section{Hakikat Metode Bercerita}

a. Pengertian Metode Bercerita

Cerita menurut Horatius (Musfiroh, 2005: 37) berarti menyenangkan dan bermanfaat. Cerita memang menyenangkan karena cerita memberikan bahan lain dari sisi kehidupan manusia. Dalam cerita banyak terkandung nilai-nilai kehidupan yang dapat diresapi dan dicerna oleh siapapun. Melalui cerita, pengalaman emosional dan intelektual dapat terbentuk. Selain itu, cerita membekali murid dengan sesuatu yang bermanfaat bagi hidup. Karena cerita yang menarik adalah menyerupai hidup yang sebenarnya, tetapi tidak sama dengan kehidupan itu sendiri (Sudjiman, 1991 dalam Musfiroh, 2005: 38).

Salah satu metode yang dapat mengembangkan keterampilan berbicara murid adalah metode bercerita. Metode bercerita merupakan salah satu metode yang dapat digunakan dalam pembelajaran Bahasa Indonesia. Konsep metode 
bercerita merupakan salah satu pemberian pengalaman belajar melalui cerita yang disampaikan secara lisan.

\section{Hakikat Keterampilan Berbicara}

Salah satu keterampilan yang harus dikembangkan oleh guru adalah keterampilan berbicara. Berbicara secara umum dapat diartikan sebagai suatu penyampaian maksud (ide, pikiran, isi hati) seseorang kepada orang lain dengan menggunakan bahasa lisan sehingga maksud tersebut dapat dipahami oleh orang lain Dengan berbicara, maka maksud yang akan disampaikan akan dipahami.

Ahmadi, Mukhsin (1990: 18) memaparkan bahwa keterampilan berbicara merupakan keterampilan mereproduksikan arus sistem bunyi artikulasi untuk menyampaikan kehendak, kebutuhan, perasaan, dan keinginan kepada orang lain. Dalam hal ini, kelangkapan peralatan vokal seseorang (lidah, bibir, hidung, dan telinga) merupakan persyaratan alamiah yang mengijinkannya dapat memproduksikan suatu ragam yang luas dari bunyi artikulasi, tekanan, nada, kesenyapan, dan lagu bicara. Keterampilan ini juga didasari oleh kepercayaan diri untuk berbicara wajar, jujur, benar, dan bertanggungjawab dengan melenyapkan problema kejiwaan, seperti rasa malu, rendah diri, ketegangan, dan berat lidah.

Dari pendapat tersebut, dalam berbicara sangat dibutuhkan kepercayaan diri yang tinggi. Hal ini karena, jika murid memiliki kepercayaan diri maka masalah-masalah yang mengganggu proses berbicara dapat dihilangkan. Berbicara adalah peristiwa proses penyampaian pesan secara lisan oleh pembicara kepada penerima pesan. Dengan kata lain, berbicara adalah menyampaikan pesan melalui bahasa lisan.

\section{Penggunaan Metode Bercerita dalam Pembelajaran Keterampilan Berbicara}

Berdasarkan uraian yang telah dijabarkan di atas, maka metode bercerita mempunyai manfaat yang sangat besar untuk mengembangkan keterampilan berbicara murid. Salah satu keterampilan yang harus dikembangkan oleh guru adalah keterampilan berbicara. Keterampilan berbicara tersebut merupakan salah satu aspek dasar dari empat keterampilan berbahasa Indonesia.

Dalam pembelajaran berbicara beberapa karakteristik yang perlu diperhatikan adalah aspek kebahasaan dan non kebahasaan. Aspek kebahasaan meliputi tekanan, ucapan, kosakata/diksi, dan struktur kalimat. Aspek non kebahasaan meliputi kelancaran, keberanian, pengungkapan materi wicara, dan sikap. 
Selain itu, metode bercerita memiliki kelebihan yaitu metode ini dapat membuat bahan pelajaran yang diajarkan menjadi lebih bermakna, dapat mengembangkan kemampuan berpikir dan berimajinasi, dapat merangsang kecerdasan berbahasa yaitu melalui menyimak, berbicara, membaca, dan menulis, memupuk kerjasama antar murid, mengembangkan keterampilan berkomunikasi dan mengolah informasi, dan mengembangkan potensi spiritual, emosional, intelektual, sosial, dan fisik.

Pembelajaran sebaiknya memperhatikan berbagai keterampilan murid. Murid yang memiliki keterampilan tentunya berprestasi dalam sekolahnya. Bahasa Indonesia merupakan mata pelajaran yang tidak dapat dilepaskan dari keterampilan berbicara. Keterampilan berbicara merupakan salah satu aspek dasar dari keterampilan berbahasa. Keterampilan berbicara yang baik tentunya berasal dari proses pembelajaran yang berkualitas dan menjadikan prestasi murid meningkat.

\section{METODE PENELITIAN}

Penelitian ini merupakan penelitian korelatif (hubungan) dengan pendekatan kuantitatif. Hubungan antar variabel dalam penelitian ini adalah hubungan kausal, bertujuan untuk mengetahui ada tidaknya pengaruh metode bercerita terhadap keterampilan berbicara.

Populasi dalam penelitian ini adalah seluruh murid kelas IV SD Negeri Mangkura 4 Makassar. Jumlah murid yang menjadi kelompok kontrol diambil dari kelas IV SD Negeri Mangkura IV Makassar yaitu 30 murid yang terdiri dari 14 murid perempuan dan 16 murid laki-laki. Analisis data yang digunakan adalah meliputi deskripsi data uji analisis akhir

\section{HASIL PENELITIAN DAN PEMBAHASAN}

\section{Deskripsi Hasil Penelitian}

Data hasil penelitian terdiri dari variabel bebas, yaitu variabel Metode Bercerita (X) dan variabel terikat Keterampilan Berbicara (Y). Selain itu, juga disajikan tabel distribusi frekuensi dan diagram batang dari distribusi frekuensi masing-masing variabel.

a. Variabel Metode Bercerita 
Data variabel metde bercerita diperoleh melalui dari tes yang terdiri dari 20 soal dengan jumlah responden 30 murid. Soal merupakan pilihan ganda dimana terdapat 4 pilihan jawaban, jawaban benar mendapatkan skor 5 dan jawaban salah mendapatkan skor 2. Skor yang diperoleh masingmasing murid dikonversikan kedalam nilai, dapat dilihat tabel berikut ini.

Tabel 1Distribusi Frekuensi Metode Bercerita

\begin{tabular}{|c|c|c|}
\hline Kelas Interval & Frekuensi & Relatif \\
\hline $0-69$ & 2 & $7 \%$ \\
\hline $70-79$ & 7 & $23 \%$ \\
\hline $80-89$ & 9 & $30 \%$ \\
\hline $90-100$ & 12 & $40 \%$ \\
\hline Jumlah & 30 & $100 \%$ \\
\hline
\end{tabular}

Berdasarkan tabel maka diagram frekuensi data metode bercerita adalah seperti pada gambar di bawah ini.

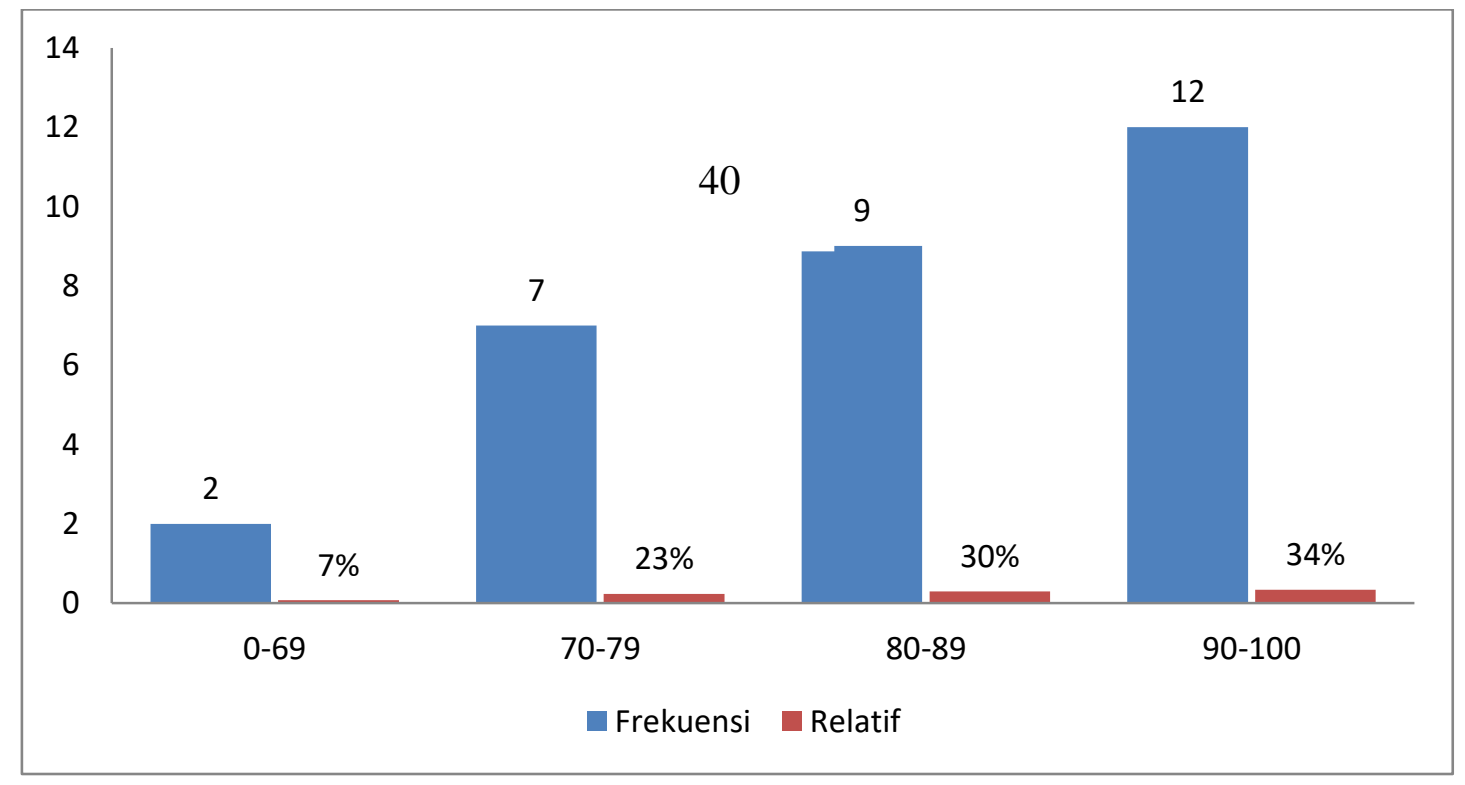

\section{Gambar 1 Diagram Batang Metode Bercerita}

b. Variabel Keterampilan Menulis Puisi Baru

Data variabel keterampilan berbicara diperoleh melalui praktek yang penilaianya sesuai dengan aspek kebahasaan yang terdiri dari tekanan, ucapan, kosa kata, dan struktur kalimat, dan non kebahasaan yang terdiri dari kelancaran, keberanian, pengungkapan wacana materi dan sikap. Ditambah tes 2 nomor dengan jumlah responden 30 murid. Skor tertinggi 
sebesar 10 dan skor terrendah 1 . Skor yang diperoleh masing-masing murid dikonversikan kedalam nilai.

Dapat dilihat pada tabel berikut ini.

Tabel 2 Distribusi Frekuensi keterampilan berbicara

\begin{tabular}{|c|c|c|}
\hline Kelas Interval & Frekuensi & Relatif \\
\hline $0-69$ & 1 & $3 \%$ \\
\hline $70-79$ & 5 & $16 \%$ \\
\hline $80-89$ & 11 & $36 \%$ \\
\hline $90-100$ & 13 & $45 \%$ \\
\hline Jumlah & 30 & $100 \%$ \\
\hline
\end{tabular}

Berdasarkan tabel maka diagram frekuensi data penggunaan metode bercerita adalah seperti pada gambar di bawah ini.

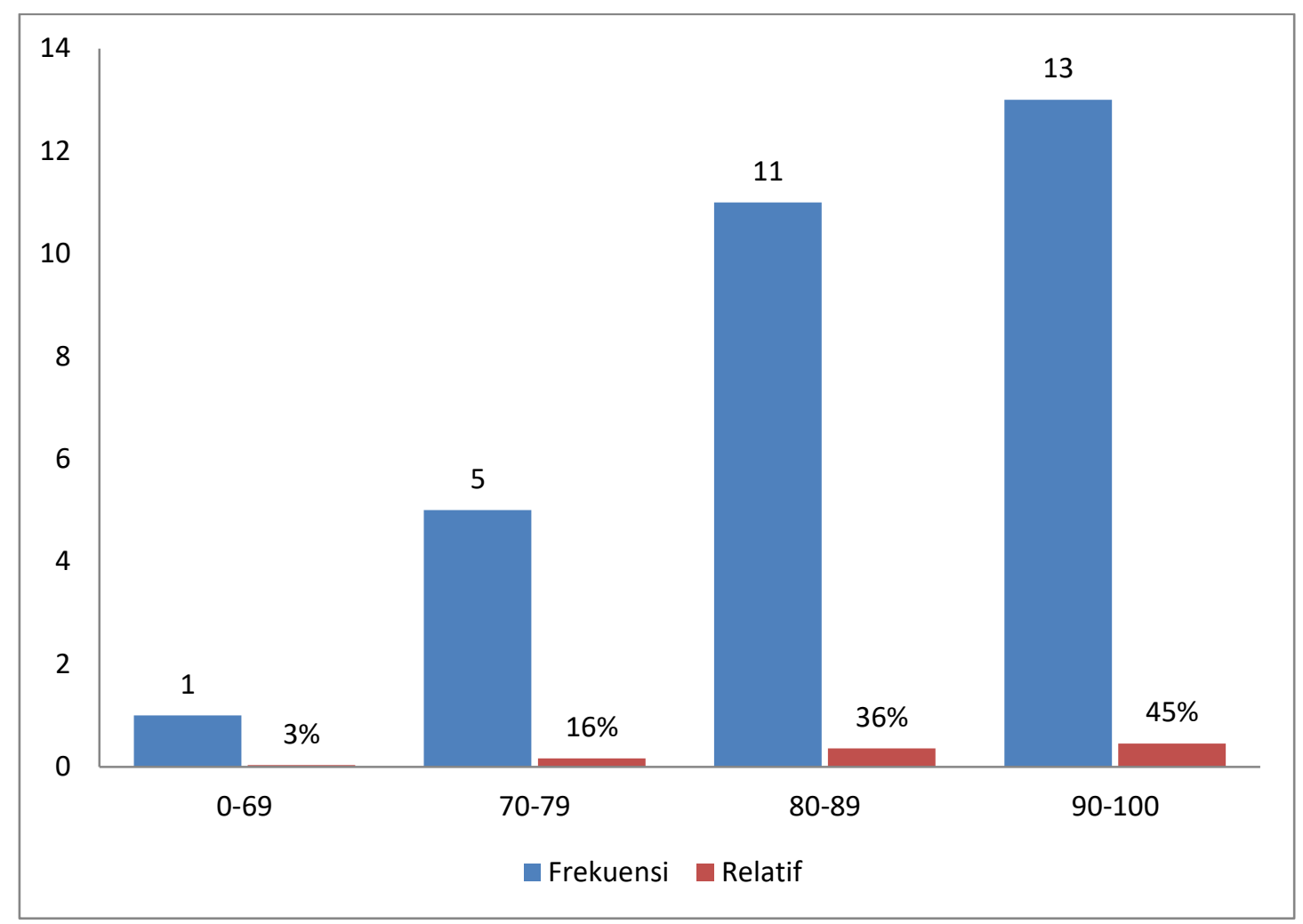

Gambar 2 Diagram Batang Keterampilan Berbicara

\section{Hasil Uji Analisis Akhir}

Hasil penelitian menggunakan rumus korelatif (hubungan) dengan pendekatan kuantitatif. Penelitian hubungan bertujuan untuk mengetahui hubungan antara dua variabel atau lebih serta mengetahui pengaruhnya. Terdapat tiga bentuk hubungan antar variabel yaitu: hubungan simetris, hubungan kausal, dan interaktif. 
Pada hasil penelitian ini digunakan hubungan kausal yang bertujuan untuk mengetahui ada tidaknya pengaruh metode bercerita terhadap keterampilan berbicara. Analisis korelasi digunakan untuk mencari hubungan ataupun pengaruh antara variabel satu dengan variabel lain yang berfungsi untuk menjelaskan, meramalkan, dan mengontrol suatu gejala.

a. Hasil Uji Hipotesis

Koefisien korelasi digunakan untuk mencari ada tidaknya pengaruh metode bercerita terhadap keterampilan berbicara dilakukan dengan menghitung koefisien korelasi antara variabel yang akan dicari pengaruhnya, koefisien merupakan angka yang menunjukkan arah dan kuatnya pengaruh antar dua atau lebih.

Tabel 3 Uji Hipotesis Manual

\begin{tabular}{|l|c|c|c|r|r|}
\hline \multicolumn{1}{|c|}{ Nama Siswa } & $\mathrm{X}$ & $\mathrm{Y}$ & $\mathrm{XY}$ & $\mathrm{X}^{2}$ & $\mathrm{Y}^{2}$ \\
\hline Abdul Arlana .R & 75 & 88 & 6600 & 5625 & 7744 \\
\hline Ahmad Farid .S. & 85 & 100 & 8500 & 7225 & 10000 \\
\hline Andi Haris Yusran & 88 & 85 & 7480 & 7744 & 7225 \\
\hline Andi Asrul & 95 & 90 & 8550 & 9025 & 8100 \\
\hline Fadel Abiyan Oktara & 60 & 65 & 3900 & 3600 & 4225 \\
\hline Fahmi Raditya Wiraska & 78 & 75 & 5850 & 6084 & 5625 \\
\hline Hasani Praditya .H & 90 & 88 & 7929 & 7744 & 8100 \\
\hline Ikhsan AL-Buchory & 88 & 80 & 6000 & 5625 & 6400 \\
\hline Kurniawan Ansyari & 80 & 88 & 7040 & 6400 & 7744 \\
\hline Muh. Firmansyah & 100 & 98 & 9800 & 10000 & 9604 \\
\hline Muh. Yusuf .A & 80 & 70 & 5600 & 6400 & 4900 \\
\hline Muh. Nur Hermawan & 90 & 100 & 9000 & 8100 & 10000 \\
\hline Putra Adryanto .Z & 70 & 85 & 5950 & 4900 & 7225 \\
\hline Resky Ilyas Irmawan & 90 & 98 & 8820 & 8100 & 9604 \\
\hline Setiawan Budi. R & 88 & 85 & 7480 & 7744 & 7225 \\
\hline Zulfikar Hidayat & 95 & 100 & 9500 & 9025 & 10000 \\
\hline Andi Aisyar Adelia .P & 80 & 78 & 6240 & 6400 & 6084 \\
\hline Andi Fatira Az-Shara & 75 & 78 & 5850 & 5625 & 6084 \\
\hline Andi Naomi Samira. R & 100 & 98 & 9800 & 10000 & 9604 \\
\hline
\end{tabular}




\begin{tabular}{|l|c|c|c|c|c|}
\hline Anandha Rayanti & 95 & 95 & 9025 & 9025 & 9025 \\
\hline Berlian Maharani .I & 95 & 90 & 8550 & 9025 & 8100 \\
\hline Dania Nur Anita & 65 & 75 & 4875 & 4225 & 5625 \\
\hline Faradiba Hardiyanti & 98 & 100 & 9800 & 9604 & 10000 \\
\hline Kezia Fadillah Islami & 85 & 80 & 6800 & 7225 & 6400 \\
\hline Larisa Andiva .K & 100 & 95 & 9500 & 10000 & 9025 \\
\hline Naila Aulia Ahmad & 78 & 88 & 6864 & 6084 & 7744 \\
\hline Nur Azizah & 80 & 85 & 6800 & 6400 & 7225 \\
\hline Nurmala dwi restafi & 95 & 100 & 9500 & 9025 & 10000 \\
\hline Pratiwi Andira .P & 70 & 85 & 5950 & 4900 & 7225 \\
\hline Syakhila Nairani .P & 95 & 98 & 9810 & 9025 & 9604 \\
\hline Jumulah & 2550 & 2640 & 227367 & 225679 & 235493 \\
\hline
\end{tabular}

$\mathbf{r}_{\mathbf{x y}}=$ Koefisien korelasi

$\sum \mathbf{X}^{2}=1920242$

$\mathbf{N}=30$

$\sum \mathbf{Y}^{2}=220134$

$\mathbf{X}=2520$

$\sum X Y=206569$

$\mathbf{Y}=2552$

\section{Perhitungan Koefisien Korelasi}

$$
\begin{aligned}
& \mathbf{r}_{\mathrm{xy}}=\frac{\mathbf{N} \sum \mathbf{X Y}-\left(\sum \mathbf{X}\right)\left(\sum \mathbf{Y}\right)}{\sqrt{\left(\mathbf{N} \sum \mathbf{X}^{2}-\left(\sum \mathbf{X}\right)^{2}\right)\left(\mathbf{N} \sum \mathbf{Y}^{2}-\left(\sum \mathbf{Y}\right)^{2}\right)}}
\end{aligned}
$$

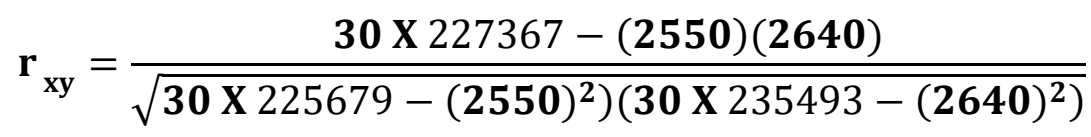

$$
\begin{aligned}
& r_{x y}=\frac{6821010-6732000}{\sqrt{(6770370-6502500)(7064790-6969600)}}
\end{aligned}
$$




$$
\begin{aligned}
& \mathbf{r}_{x y}=\frac{89010}{\sqrt{(267870)(95190)}} \\
& r_{x y}=\frac{89010}{\sqrt{25498545300}} \\
& r_{x y}=\frac{89010}{159682.6393} \\
& r_{x y}=0.5579=0.558
\end{aligned}
$$

Dilihat dari interpretasi koefisien, antara variabel $\mathrm{x}$ dan $\mathrm{y}$ terdapat tingkat pengaruh yang cukup kuat atau sedang.

\section{Koefisien Determinan}

$$
\begin{aligned}
& \mathbf{K D}=\mathbf{r}^{2} \mathbf{X 1 0 0} \% \\
& \mathbf{K D}=(\mathbf{0 5 5 8})^{2} \times \mathbf{1 0 0} \% \\
& \mathbf{K D}=\mathbf{0 . 3 1 1 3} \times \mathbf{1 0 0} \% \\
& \mathbf{K D}=\mathbf{3 1 . 1 3} \%
\end{aligned}
$$

b. Hasil Uji Signifikansi

Uji signifikansi adalah salah satu tahap terpenting dalam sebuah penelitian. Uji signifikansi untuk menentukan apakah hipotesis yang dibuat dari awal diterim atau ditolak. Hipotesis dalam suatu penelitian merupakan pernyataan awal atau dugaan yang memerlukan pengujian untuk menentukan kebenaran

$$
\begin{aligned}
& t_{\text {hitung }}=\frac{r \sqrt{n-2}}{\sqrt{1-r^{2}}} \\
& t_{\text {hitung }}=\frac{0.558 \sqrt{30-2}}{\sqrt{1-0.558^{2}}} \\
& t_{\text {hitung }}=\frac{0.558 \sqrt{28}}{\sqrt{1-0.558^{2}}} \\
& t_{\text {hitung }}=\frac{0.558 \sqrt{30-2}}{0.829}
\end{aligned}
$$

$$
\begin{aligned}
& t_{\text {hitung }}=\frac{5.291}{0.829} \\
& t_{\text {hitung }}=3.560
\end{aligned}
$$

Dari hasil analisis data menunjukkan bahwa rata-rata pengaruh metode bercerita terhadap keterampilan berbicara siswa kelas IV SD Negeri Mangkura 4 Makassar sebesar 72,82\% menunjukkan kecenderungan metode bercerita siswa 
dalam kategori "Baik". Setiap kenaikan variabel independen (metode bercerita) akan mengikuti kenaikan variabel dependen (keterampilan berbicara).

Metode bercerita adalah penyampaian atau penyajian materi pembelajaran secara lisan dalam bentuk cerita. Metode bercerita sangat berhubungan dengan keterampilan berbicara yang mengandung dua aspek, yaitu aspek kebahasaan dan non kebahasan yang cocok digabungkan dengan metode bercerita. Untuk menguji keberartian pengaruh masing-masing variabel bebas dan terikat dilakukan pengujian hipotesis Dalam penelitian ini yang dimaksud variabel bebas metode bercerita (X) dan keterampilan berbicara (Y).

Berdasarkan hasil perhitungan analisis hipotesis adalah 0.558. Selain uji hipotesis diuji juga dengan nilai koefisien determinasi sebesar 31.13\%. Uji terakhir yang dilakukan adalah uji signifikansi untuk mengetahui apakah hipotesis yang dibuat dari awal diterima atau ditolak dari. Hasil uji signifikansi adalah sebesar 3.560 dengan kata lain bahwa hipotesis yang berbunyi "Ada pengaruh metode berbicara terhadap keterampilan berbicara murid kelas IV SD Negeri Mangkura 4 Makassar Kecamatan Ujung Pandang, Kelurahan Sawerigading, Kota Makassar, Sulawesi Selatan diterima dan $\mathrm{H}_{0}$ ditolak.

\section{SIMPULAN DAN SARAN}

Pembelajaran berbicara dengan menggunakan metode becerita dapat mempengaruhi keterampilan berbicara pada murid kelas IV SD Negeri Mangkura 4 Makassar Kecamatan Ujung Pandang, Kelurahan Sawerigading, Kota Makassar, Sulawesi Selatan. Metode bercerita dapat meningkatkan aktivitas pembelajaran yang ditunjukkan dengan beberapa aspek, yaitu murid bersemangat untuk membaca cerita yang dipilihkan oleh guru. Murid memperhatikan contoh guru bercerita. Murid berani bertanya jawab yang berhubungan dengan cerita. Murid menuliskan unsur-unsur cerita dan membacakannya di depan kelas. Murid berlatih bercerita dengan kelompoknya, membaca dua sampai tiga kali cerita untuk memahami karakter setiap tokoh. Murid antusias untuk maju bercerita. Murid menyimak teman yang lain saat bercerita. Murid berani bercerita di depan kelas dengan penuh kesungguhan. Murid menyimpulkan cerita yang telah disampaikan. Murid berani mengekspresikan perasaan mereka setelah bercerita. Hasil penelitian yang dilaksanakan kelas IV SD Negeri Mangkura 4 Makassar Kecamatan Ujung Pandang, Kelurahan Sawerigading, Kota Makassar, Sulawesi 
Selatan menunjukan jika metode bercerita dan keterampilan berbicara saling berpengaruh dalam hasil belajar dan aktivitas belajar murid.

Saran yang dapat diberikan: (1) Guru dalam melaksanakan pembelajaran sebaiknya menggunakan metode pembelajaran yang menarik pada mata pelajaran Bahasa Indonesia sehingga aktivitas dan hasil belajar murid dapat meningkat. (2) Penggunaan metode bercerita dalam pembelajaran berbicara dapat dijadikan alternatif dalam upaya meningkatkan keterampilan berbicara murid yang mengutamakan aktivitas murid. (3) Ada keterbatasan terkait proses pembelajaran yaitu masih terdapat aktivitas yang berpusat pada guru. Hal ini dapat dijadikan masukan untuk penelitian berikutnya, bahwa pembelajaran harus berpusat pada murid.

\section{DAFTAR PUSTAKA}

Akhadiah, dkk 1991. Pembinaan Kemampuan Menulis Bahasa Indonesia Jakarta: Penerbit Erlangga

Ahmadi, Mukhsin. 1990. Strategi Belajar Mengajar Keterampilan Berbahasa dan Apresiasi Sastra. Malang: YA 3 Malang.

Amier, Muhammad, 2014. Pendidikan Keterampilan Berbahasa. Makassar: Unismuh Makassar

Arsjad, Maidar G, 1988. Pembinaan Kemampuan Berbicara Bahasa Indonesia. Jakarta: PT Gelora Aksara Pratama.

Arikunto, Suharsimi, 2006. Metodelogi Penelitian. Yogyakarta: Bina Asara.

Cipta.

Bachri, Bachtiar S, 2005. Pengembangan Kegiatan Bercerita Di Taman Kanakkanak, Teknik, dan Prosedurnya. Jakarta: Dirjen Dikti.

Bungin, Burhan, 2013. Metodologi Penelitian Sosial dan Ekonomi. Jakarta: Kencana Prenada Media Group.

Djiwandono, M. Soenardi. 1996. Tes Bahasa Dalam Pengajaran. Bandung: Penerbit ITB.

Hadi, Sutrisno, dkk. 2013. Metodologi Penelitian. Jakarta: PT. Bumi Aksara.

Haryadi dan Zamzani. (1996/1997). Peningkatan Keterampilan Berbahasa Indonesia. Jakarta: Depdikbud.

Hasan, M. Iqbal, 2001. Metodologi Penelitian. Bogor: Ghalia Indonesia

Jonathan, Sarwono, 2006. Metode Penelitian Kuantitatif dan Kualitatif. Yogyakarta:Graha Ilmu 
Margono, 2007. Metodologi Penelitian Pendidikan Komponen MKDK. Jakarta: PT. Rineka Cipta.

Musfiroh, Tadkiroatun, 2005. Bercerita untuk Anak Usia Dini. Jakarta: Dirjen Dikti.

Moeslichatoen, Metode penajaran di taman kanak-kanak, Malang: Rhieka Cipta

Nurancana, Wayan, 1992. Evaluasi Hasil Belajar. Surabaya: Usaha Nasional.

Noor, Juliansyah, 2011. Skripsi, Tesis, Disertasi \& Karya Ilmiah. Jakarta: Kencana Prenada Media Group.

Prabantara, Esti Wijayanti, 2015. Peningkatan Keterampilan Berbicara Riduwan, 2004. Metode Riset. Jakarta: PT. Rineka Cipta.

Rofi'uddin dan Zuhdi, Ahmad dan Darmiyati. (1998/1999). Pendidikan Bahasa dan Sastra Indonesia di Kelas Tinggi. Jakarta: Dirjen Dikti.

Sibarani, Robert, 2004. Antropolinguistik. Medan: Poda

Sukmadinata, Nana, Syaodih, 2013. MetodePenelitian Pendidikan. Bandung: Remaja Rosdakarya.

Sugihartono, dkk, 2007. Psikologi Pendidikan. Yogyakarta: UNY Press.

Sugiyono, 2011 Statistika Untuk Penelitian. Bandung: Alfabeta CV.

, 2010. Pendekatan Penelitian Kuatintatif, kualitatif dan R\&D. Bandung: Alfabeta.

Tarigan, Henry Guntur 2008. Berbicara Sebagai Suatu Keterampilan Berbahasa. Bandung: Angkasa Bandung.

Usman, Moh Uzer 2006 Menjadi Guru Profesional. Bandung: Remaja Rosdakarya

Wuryandani, Wuri 2011. Pembelajaran PKn di Sekolah Dasar. Yogyakarta: Nuha Litera. 